\title{
A Study on the Perceptions of Students on Renewable Energy at Süleyman Demirel University in Isparta, Turkey
}

\author{
Hilal YAKUT İPEKOĞLU, İbrahim ÜÇGÜL, Gamze YAKUT \\ Süleyman Demirel University, Isparta, Turkey
}

\begin{abstract}
Recent research suggests that public opinion's acknowledgment is a major obstacle in the way of renewable energy use. Renewable energy will be more preferred and available through social and individual perception and awareness-raising. However, first of all, it is necessary to identify the existing perception and demographical factors affecting it to achieve renewable energy perception. In this regard, perceptions of students studying at different departments of faculties and vocational schools at Süleyman Demirel University on renewable energy and the factors affecting their perceptions were studied. According to the research results, there was not a significant difference between students' hometowns, parents' occupations and renewable energy perception. However, there was a significant difference between parents' educational background, monthly income and students' renewable energy future tendency. Mother's educational background was also effective on renewable energy future vision, and there was a significant difference between students' faculties and renewable energy perception.
\end{abstract}

Keywords: educational background, income, occupation, perception, renewable energy

\section{Introduction}

Energy has become the most important concept mapping the future of countries today. In the sense of Turkey, energy takes place at the center of today's national plannings. According to the Republic of Turkey Ministry of Development's Tenth Development Plan ${ }^{1}$ spanning the years of 2014 to 2018, Turkey aims at preeminently using local and renewable energy sources. According to this aim, which is involved in the Republic of Turkey Ministry for European Union Affairs ${ }^{2}$, Directorate of Sectoral Policies' European Union Energy Policy, it is necessary to reduce the dependence on foreign sources and increase the share of renewable energy sources in the production of energy. Similarly, the objectives and goals of the Republic of Turkey National Climate Change Action Plan (from 2011 to 2023) include increasing the use of renewable energy sources. According to the National Communication of Turkey on Climate Change (Apak \& Ubay, 2007), studies which will promote the production and use of renewable energy sources are planned and the removal of

Hilal YAKUT İPEKOĞLU, Asst. Prof., Department of Anthropology, Süleyman Demirel University.

İbrahim ÜÇGÜL, Assoc. Prof., Department of Textile Engineering, Süleyman Demirel University.

Gamze YAKUT, Ph.D., Department of Mechanical Engineering, Süleyman Demirel University.

1 Republic of Turkey Ministry of Development, Tenth Development Plan (2014-2018). 2013. Ankara. http://www.eigm.gov.tr/File/?path=ROOT\%2f4\%2fDocuments\%2fEnerji+Politikas\%C4\%B1\%2fOnuncu+Kalk\%C4\%B1 nma+P1 an\%C4\%B1+(2014-2018).pdf (accessed 01 March 2015).

${ }^{2}$ Republic of Turkey Ministry for European Union Affairs, Sectoral Policies Directorate, Chapter 15: European Union Energy Policy on Energy. http://www.ab.gov.tr/index.php?1=1\&p=80 (accessed 01 March 2015).

3 Republic of Turkey Ministry of Environment and Urbanisation, National Climate Change Action Plan (2011-2023). https://www.csb.gov.tr/db/iklim/banner/banner591.pdf (accessed 02 March 2015). 
particularly financial and legal obstacles is considered among the priority issues.

Many future plans prepared for Turkey heavily emphasize the issue of energy, especially the issue of clean and renewable energy. Some financial and legal regulations have been made with the aim of increasing renewable energy sources within the framework of action plans. However, some deficiencies were noted in the regulations regarding how to manage energy and the change in energy use in the individual and social context.

When the relevant literature is reviewed, it can be seen that there are several factors defined which affect renewable energy use. Painuly (2001) defines the obstacles in the way of widespread use of renewable energy as market shortage, market failure, economic and financial reasons, institutional obstacles, technical obstacles and social, cultural and behavioral obstacles. In the social, cultural and behavioral context, the obstacles include product safety, consumer's acknowledgment of product, and the lack of social acknowledgment for some renewable energy sources. Many studies conducted on renewable energy from social and cultural perspective in the previous nearly a decade reveal the importance of individual acknowledgment (Devine-Wright 2007; Wüstenhagen, Wolsink, \& Bürer, 2007; West, Bailey, \& Winter, 2010; Howell, Shackley, \& Mabon, 2012; Vaijayanthi, 2013; Zyadin, Puhakka, Ahponen, \& Pelkonen, 2014; Alam et al., 2014; Songsore \& Buzzeli, 2014). These studies proved that human is the key factor in increasing the rate of renewable energy use and accelerating technological advancements in the field. The choice and prevalence of energy sources at social and individual scale are directly linked to public opinion's lack of knowledge and prejudices. The fact that individuals have a positive perception about clean and renewable energy sources will lead them to prefer these energy sources within the bounds of possibility. However, negative stimuli that do not include accurate information will affect choice, priority and widespread use of energy sources. Education forms the basis of accurate information, accurate perceptions, and therefore, accurate attitude and behaviors in this context as it does in every other context. According to Zyadin et al. (2014), it is necessary for official and unofficial institutions to transfer an easy and understandable education model to individuals. This is the only way to relieve prejudices and ensure participation.

Studies on renewable energy from the perspective of society and individual have been conducted in Turkey, too. In their study Ediger and Kentmen (2010) conclude that Turkish people are mostly illiterate in the context of renewable energy. Researchers relate this situation to the lack of education and ignorance of media on this matter. Karatepe, Varbak Neşe, Keçebaş, and Yumurtacı (2012) did a study on determining Turkish university students' awareness levels about renewable energy sources. This study revealed that students or graduates of technical education faculties should become qualified technical personnel and be sensitive to the environment. Therefore, it is argued that there is a need for various activities conducted in education programs, at courses and schools in order to raise awareness in this field. Çelikler (2013) tested the students enrolled at primary science teaching on the awareness of renewable energy sources. Saraç and Bedir (2014) conducted a study on primary classroom teachers' perceptions of renewable energy sources. According to the results of the qualitative study, they found that teachers lack knowledge in renewable energy sources, confuse concepts and have quite low perceptions on this matter.

Globally, human is the key factor affecting the advancement of innovations in energy sector and the rate of energy use. Individuals and societies' perceptions, prejudices, and lack of knowledge are influential on preference for clean energy and type of use. The need for the change of perceptions in the context of renewable energy sources leads researchers to investigate the facts that produce this perception. Many stimuli we have 
been exposed to in our lifetime shapen our perceptions of events and facts. It is natural that our perceptions of renewable energy sources are influenced by environmental conditions that we live in, our families' perceptions, the impressions we receive of the stimuli such as radio, television, and Internet and all that we have learned in our education life. Therefore, families' educational background, occupations, and income levels since renewable energy sources are expensive to set up in today's economic conditions, renewable energy practices within neighborhood, and the education we receive are likely to affect our perceptions of renewable energy sources.

With reference to these hypotheses, this study aims to determine the perception of renewable energy and the factors affecting this perception with an interdisciplinary approach that brings anthropology and engineering together. The perceptions of university students studying at different faculties, vocational schools and departments and the factors affecting their perceptions were determined by means of a scale developed previously by the authors of this study (Yakut İpekoğlu, Üçgül, \& Yakut, 2014).

\section{Method}

The subscales of Renewable Energy Technical Knowledge, Renewable Energy-Environment Relationship, Renewable Energy Future Vision, and Renewable Energy Future Tendency, previously developed by Yakut İpekoğlu et al., were used in this study. The study aimed to obtain a large number of samples in a short time using the quantitative data collection method.

Renewable Energy Technical Knowledge questions were used to assess students' technical knowledge regarding various energy types and how to produce renewable energy sources such as the sun, wind, geothermal energy, bioenergy, and biodiesel. Renewable Energy-Environment Relationship questions were used to assess students' way of perceiving the impact of renewable energy on natural environment, animals, plants, and humans. Renewable Energy Future Vision questions focused on Turkish and global energy consumption preferences in the future to determine students' visions and future perceptions on this matter. Renewable Energy Future Tendency questions were used to ask students whether they will use renewable energy sources in the future or not and determine their possible preferences on this matter.

In addition to the scales in the questionnaire, detailed demographical questions were also used to determine other variables that may affect perception. According to this, indexed and rated variables like age, gender, parents' educational background, parents' occupations, monthly income, and neighborhood were added to the questionnaire.

Six research questions were developed to determine students' perceptions of renewable energy and the demographical factors affecting their perceptions in accordance with the purpose of the study and the scale:

(1) Is there a significant relationship between students' parents' occupations and students' perceptions of renewable energy knowledge (technical knowledge and knowledge of energy-environment relationship), renewable energy future vision and renewable energy future tendency?

(2) Is there a significant relationship between students' parents' educational background and students' perceptions of renewable energy knowledge (technical knowledge and knowledge of energy-environment relationship), renewable energy future vision and renewable energy future tendency?

(3) Is there a significant relationship between students' parents' monthly income and students' perceptions of renewable energy knowledge (technical knowledge and knowledge of energy-environment relationship), renewable energy future vision and renewable energy future tendency? 
(4) Is there a significant relationship between students' hometowns and students' perceptions of renewable energy knowledge (technical knowledge and knowledge of energy-environment relationship), renewable energy future vision and renewable energy future tendency?

(5) Is there a significant relationship between students' faculties and students' perceptions of renewable energy knowledge (technical knowledge and knowledge of energy-environment relationship), renewable energy future vision and renewable energy future tendency?

(6) Is there a significant relationship between students' scores of renewable energy knowledge (technical knowledge and knowledge of energy-environment relationship), renewable energy future vision and renewable energy future tendency?

The research population is composed of university students and the research sample is composed of university students registered in different classes in different faculties and vocational schools at Süleyman Demirel University in Isparta. The data were collected during the spring, summer and fall semesters in the academic year of 2015. The scale was implemented to the students registered in the Faculty of Technology, Faculty of Engineering, Faculty of Economics and Administrative Sciences, Faculty of Science and Letters, Faculty of Health Sciences, Gönen Vocational School, Senirkent Vocational School, and Isparta Vocational School. The diversity of faculty, vocational school and department was taken into account in the research study in order to make generalizations in accordance with the sample of Süleyman Demirel University students. 405 students participated in the research study from the Departments of Energy Systems Engineering, Electrical and Electronics Engineering, Textile Engineering, Chemical Engineering, Computer Engineering, Food Engineering, Mechanical Engineering, Geophysical Engineering, Environmental Engineering, Labor Economics, Health Administration, Finance, Business Administration, Tourism Management, Public Administration, International Relations, Biology, Archeology, History, Sociology, English Language and Literature, Geography, Physical Therapy and Rehabilitation, Nursing, Midwifery, Banking and Insurance, Architectural Decorative Arts, Fashion Design, Electrical Technician, Radio and Television, Logistics, Graphic Design, Construction, and Health Institutions Management.

The first step in the data analysis procedure was to check the distribution of variables using frequency analysis. As the data were not parametric, a decision was made on which non-parametric analysis method was appropriate to use for answering the research questions. The Spearman's Rank Correlation Coefficient was used to test the significance of the correlations between the answers given to the scales. The Kruskal Wallis-H test was used for the relationship between the demographical variables and the answers given to the scales.

\section{Findings}

The answers given to the research questions, which were prepared to determine university students' perceptions of renewable energy and the demographical factors affecting their perceptions, were specified as a result of the statistical analyses conducted. The first research question was to test whether there was a relationship or not between students' parents' occupations and students' perceptions of renewable energy.

The Kruskal Wallis-H test was used for the answer to the research question "Is there a significant relationship between students' parents' occupations and students' perceptions of renewable energy knowledge (technical knowledge and knowledge of energy-environment relationship), renewable energy future vision and renewable energy future tendency?". As a result of the test, it was found that there was not a significant difference between the subscale scores of students' parents' occupations and renewable energy perception $(p>0.05)$. 
The second question related to the identification of the relationship between parents' educational background and renewable energy perception. The Kruskal Wallis-H test was used for the answer to the research question "Is there a significant relationship between students' parents' educational background and students' perceptions of renewable energy knowledge (technical knowledge and knowledge of energy-environment relationship), renewable energy future vision and renewable energy future tendency?". As a result of the test, it was found that there was a significant difference between Future Vision $\left[\chi^{2}(6)=13.778, p\right.$ $<0.05]$ and Future Tendency $\left[\chi^{2}(6)=14.304, p<0.05\right]$. According to the mean ranks, students whose mothers held bachelor's, master's or doctoral degrees got higher scores. The mean ranks and the Kruskal Wallis-H test scores were given in Table 1.

Table 1

The Kruskal Wallis-H Test Results of the Renewable Energy Perception Subscale According to Mother's Educational Background

\begin{tabular}{|c|c|c|c|c|c|c|}
\hline & Group & $n$ & Mean Rank & $s d$ & $\chi^{2}$ & $p$ \\
\hline \multirow{7}{*}{ Future Vision } & Doctor's degree & 1 & 352.5 & 6 & 13.778 & 0.05 \\
\hline & Master's degree & 2 & 294.5 & & & \\
\hline & Baclehor's degree & 18 & 213.14 & & & \\
\hline & High school graduate & 58 & 205.25 & & & \\
\hline & Secondary school graduate & 58 & 184.01 & & & \\
\hline & Primary school graduate & 230 & 183.37 & & & \\
\hline & Associate's degree & 7 & 85.07 & & & \\
\hline \multirow{7}{*}{ Future Tendency } & Doctor's degree & 1 & 371.5 & 6 & 14.304 & 0.05 \\
\hline & Baclehor's degree & 18 & 245.25 & & & \\
\hline & High school graduate & 61 & 220.34 & & & \\
\hline & Primary school graduate & 236 & 185.84 & & & \\
\hline & Master's degree & 2 & 185 & & & \\
\hline & Secondary school graduate & 61 & 182.11 & & & \\
\hline & Associate's degree & 6 & 123.58 & & & \\
\hline
\end{tabular}

Table 2

The Kruskal Wallis-H Test Results of the Renewable Energy Perception Subscale According to Father's Educational Background

\begin{tabular}{lllllll}
\hline & Group & $n$ & Mean Rank & $s d$ & $\chi^{2}$ & $p$ \\
\hline & Doctor's degree & 1 & 350 & 6 & 13.543 & 0.05 \\
& Master's degree & 3 & 317.5 & & & \\
& Associate's degree & 15 & 242.43 & & & \\
Future Tendency & Baclehor's degree & 89 & 225.23 & & & \\
& High school graduate & 165 & 188.2 & & & \\
& Primary school graduate & 83 & 178.45 & & \\
& Secondary school graduate & 178.07 & & & \\
\hline
\end{tabular}

As a result of the test undertaken to discover the relationship between father's educational background and the answers given to the scale, it was found that there was a significant relationship between future tendency $\left[\chi^{2}\right.$ $(6)=14.304, p<0.05]$ and father's educational background. As can be seen in Table 2, students whose fathers held bachelor's, master's or doctoral degrees got higher scores in the subscale of future tendency, as in the case of mother's educational background. 
The third research question related to the identification of the relationship between family's monthly income and perception: "Is there a significant relationship between students' parents' monthly income and students' perceptions of renewable energy knowledge (technical knowledge and knowledge of energy-environment relationship), renewable energy future vision and renewable energy future tendency?". As a result of the analysis, there was a significant difference between future tendency and monthly income $\left[\chi^{2}(5)=\right.$ $13.741, p<0.01]$. The higher the family's income is, the higher the students' scores of renewable energy future tendency are. The scale scores according to family's income are presented in Table 3.

Table 3

The Kruskal Wallis-H Test Results of the Renewable Energy Perception Subscale According to Family's Income Level

\begin{tabular}{lllllll}
\hline & Group & $n$ & Mean Rank & $s d$ & $\chi^{2}$ & $p$ \\
\hline & 4500 and more than & 16 & 264.22 & 5 & 13.714 & 0.01 \\
& $4500-3500$ & 21 & 237.02 & & & \\
Future Tendency & $3500-2500$ & 54 & 194.97 & & & \\
& $2500-1500$ & 99 & 174.67 & & & \\
& $1500-$ Minimum wage & 138 & 188.03 & & & \\
& Minimum wage and less than & 52 & 181.1 & & & \\
\hline
\end{tabular}

The fourth research question aimed to determine the relationship between students' hometown and perception. When the answers to the question "Is there a significant relationship between students' hometowns and students' perceptions of renewable energy knowledge (technical knowledge and knowledge of energy-environment relationship), renewable energy future vision and renewable energy future tendency?" were considered, it appeared that there was not a significant relationship between students' hometowns and the subscales of renewable energy perception $(p>0.05)$.

The fifth research question related to the identification of the relationship between students' faculties and their perceptions of renewable energy: "Is there a significant relationship between students' faculties and students' perceptions of renewable energy knowledge (technical knowledge and knowledge of energy-environment relationship), renewable energy future vision and renewable energy future tendency?". The Kruskal Wallis-H test for independent assessments was used to determine whether or not there was a significant difference between students' faculties and the answers given to the subscales. As a result, significant differences were discovered between students' answers to the subscales of Renewable Energy Technical Knowledge $\left[\chi^{2}(5)=33.696, P<0.01\right]$, Energy-Environment Knowledge $\left[\chi^{2}(5)=23.94, P<0.01\right]$, Future Vision $\left[\chi^{2}(5)=13.412, P<0.05\right]$ and Future Tendency $\left[\chi^{2}(5)=23.098, P<0.01\right]$ in terms of students' faculties. When the mean ranks given in Table 4 are considered, it can be seen that students from the Faculty of Technology got the highest scores, followed by the students from the Faculty of Science and Letters. The lowest level of knowledge belongs to vocational schools. The highest mean rank belongs to the Faculty of Science and Letters in terms of energy-environment knowledge, followed by the Faculty of Engineering. With respect to future vision, the highest mean rank belongs to the Faculty of Engineering and the lowest mean rank belongs to vocational schools. With respect to future tendency, the highest mean rank belongs to the Faculty of Technology, followed by the Faculty of Economics and Administrative Sciences. The lowest mean rank, on the other hand, belongs to vocational schools. 
Table 4

The Kruskal Wallis-H Test Results of the Renewable Energy Perception Subscale According to Faculties

\begin{tabular}{|c|c|c|c|c|c|c|}
\hline & Group & $n$ & $\begin{array}{l}\text { Mean } \\
\text { Rank }\end{array}$ & $s d$ & $\chi^{2}$ & $p$ \\
\hline \multirow{6}{*}{$\begin{array}{l}\text { Technical } \\
\text { Knowledge }\end{array}$} & Faculty of Technology & 69 & 211.96 & 5 & 33.696 & 0.000 \\
\hline & Faculty of Science and Letters & 15 & 208.83 & & & \\
\hline & Faculty of Economics and Administrative Sciences & 93 & 193.86 & & & \\
\hline & Faculty of Health Sciences & 50 & 159.31 & & & \\
\hline & Faculty of Engineering & 32 & 148.28 & & & \\
\hline & Vocational Schools & 87 & 132.57 & & & \\
\hline \multirow{6}{*}{$\begin{array}{l}\text { Knowledge of } \\
\text { energy-environment } \\
\text { relationship }\end{array}$} & Faculty of Science and Letters & 15 & 212.33 & 5 & 23.94 & 0.000 \\
\hline & Faculty of Engineering & 35 & 211.26 & & & \\
\hline & Faculty of Economics and Administrative Sciences & 100 & 206.31 & & & \\
\hline & Faculty of Health Sciences & 51 & 198.51 & & & \\
\hline & Faculty of Technology & 72 & 196.35 & & & \\
\hline & Vocational Schools & 100 & 142.8 & & & \\
\hline \multirow{6}{*}{ Future Vision } & Faculty of Engineering & 35 & 218.83 & 5 & 13.412 & 0.02 \\
\hline & Faculty of Science and Letters & 15 & 215.2 & & & \\
\hline & Faculty of Technology & 73 & 214.39 & & & \\
\hline & Faculty of Economics and Administrative Sciences & 102 & 204.22 & & & \\
\hline & Faculty of Health Sciences & 55 & 182.19 & & & \\
\hline & Vocational Schools & 107 & 165.32 & & & \\
\hline \multirow{6}{*}{ Future Tendency } & Faculty of Technology & 75 & 240.57 & 5 & 23.098 & 0.000 \\
\hline & Faculty of Economics and Administrative Sciences & 103 & 213.65 & & & \\
\hline & Faculty of Science and Letters & 17 & 205.74 & & & \\
\hline & Faculty of Engineering & 37 & 201.08 & & & \\
\hline & Faculty of Health Sciences & 56 & 186.93 & & & \\
\hline & Vocational Schools & 110 & 163.16 & & & \\
\hline
\end{tabular}

The sixth question was prepared to determine the relationship between the subscales developed to assess renewable energy perception. The Spearman's Rank Correlation Coefficient was calculated to test the question "Is there a significant relationship between students' scores of renewable energy knowledge (technical knowledge and knowledge of energy-environment relationship), renewable energy future vision and renewable energy future tendency?". During the analysis, students' subscale scores were compared and the relationships between them were determined. According to the results, there was a significant but low-level relationship between the scores students received from the subscales of Renewable Energy Technical Knowledge and Renewable Energy-Environment Knowledge $(r=0.288, p<0.01)$ and between the Renewable Energy Environment and Renewable Energy Future Vision scores $(r=0.119, p<0.05)$. It appeared that there was a medium-level relationship between technical knowledge and future vision $(r=0.383, p<0.01)$, and future tendency $(r=0.505, p<0.01)$. There was a medium-level $(r=0.455, p<0.01)$ relationship between future tendency and future vision, too. It also appeared that there was a low-level $(r=0.248, p<0.01)$ relationship between energy-environment knowledge and future tendency. The results of the analysis were given in Table 5 . 
Table 5

The Spearman's Rank Correlation Coefficient Results of the Subscales

\begin{tabular}{|c|c|c|c|c|}
\hline & & Technical Knowledge & $\begin{array}{l}\text { Knowledge of } \\
\text { energy-environment } \\
\text { relationship }\end{array}$ & Future Vision \\
\hline \multirow{3}{*}{$\begin{array}{l}\text { Knowledge of } \\
\text { energy-environment } \\
\text { relationship }\end{array}$} & Correlation Coefficient & $0.288\left(^{* *}\right)$ & & \\
\hline & Sig. (2-tailed) & 0 & & \\
\hline & $N$ & 331 & & \\
\hline \multirow{3}{*}{ Future Vision } & Correlation Coefficient & $0.383\left(^{* *}\right)$ & $0.119\left(^{*}\right)$ & \\
\hline & Sig. (2-tailed) & 0 & 0.023 & \\
\hline & $N$ & 337 & 362 & \\
\hline \multirow{3}{*}{ Future Tendency } & Correlation Coefficient & $0.505\left(^{* *}\right)$ & $0.248\left(^{* *}\right)$ & $0.455\left(^{* *}\right)$ \\
\hline & Sig. (2-tailed) & 0 & 0 & 0 \\
\hline & $N$ & 345 & 372 & 385 \\
\hline
\end{tabular}

Notes. ${ }^{* *} p<0.01 ;{ }^{*} p<0.05$.

\section{Discussion and Conclusion}

In this study, which investigates the factors affecting renewable energy perception, the research questions formed in accordance with some hypotheses were tried to be answered with the data obtained from the students of Süleyman Demirel University. As a result of the statistical analyses conducted, it was inferred that some of the variables considered to affect energy perception were related to the subscales of renewable energy perception and affected the subscale scores. On the other hand, it was inferred that some variables had no effect on perception.

According to the analyses, parents' occupations had no effect on renewable energy perception. However, parents' educational background affected students' perception of renewable energy, especially the scores of future vision and future tendency on this matter. It was revealed that as the parents' educational level increases, students increasingly prefer using renewable energy sources in the future. In addition to this, it appeared that especially mother's educational background was effective on renewable energy future vision. Family's income level, on the other hand, was an influential factor on renewable energy future tendency. Income is an important determinant of renewable energy sources. There are many other problems facing developing countries other than clean energy use and environmental awareness on countries basis (Eshchanov et al., 2011). It is not wrong to think that a similar situation exists on a society basis, too. In contrast to the hypothesis formulated, students' hometown had no effect on their perceptions of renewable energy. There are a great number of students at Süleyman Demirel University coming from Aegean, Mediterranean and Marmara regions, where especially renewable energy sources are used. However, it appeared that the students' perceptions on this matter were independently of their hometowns. The last variable supposed to be related to the perception of renewable energy was students' faculties. According to the analyses, it was inferred that there were significant relationships between university majors and the students' answers to the subscales of renewable energy perception. It appeared that the students of the Faculty of Technology got higher scores in terms of technical knowledge while the students of the Faculty of Science and Letters got higher scores in terms of energy and environment relationship. The faculty of Science and Letters comes the second in the list, followed by the faculty of Economics and Administrative Sciences, in terms of technical knowledge. Although the Faculty of Engineering comes the second in terms of energy environment relationship, it comes at the bottom of the list in 
terms of technical knowledge, which means there is a need for the students of the Faculty of Engineering to be informed about renewable energy sources. It appeared that the students of the Faculty of Engineering got the highest scores in the subscale of future vision while they fell behind the Faculty of Technology, the Faculty of Economics and Administrative Sciences and the Faculty of Science and Letters in terms of future tendency. Although it is good news that the students of the Faculty of Economics and Administrative Sciences, who are prospective administrators, have positive perceptions of renewable energy, the perceptions of students from different branches of engineering are worrying. The result that the perceptions of vocational school students, who will meet the need for technical support in the future, fell behind others necessitates amendment of the conditions on this matter. It is necessary to enhance the perceptions of university students, who will become users of clean and environment-friendly energy sources and pass this on to the next generation. This can be achieved through accurate and reliable knowledge. The fact that today's students from different disciplines have knowledge and a positive perception of renewable energy will positively affect the public opinion's acknowledgment as well as their families' and social circle's when they begin to work.

In conclusion, the biggest obstacle in the way of increasing the choice and use of renewable energy sources is social and individual acknowledgment. It will be possible to overcome these obstacles by identifying and managing the perception of renewable energy. The best way of doing this is to conduct research studies that bring different disciplines together and manage public opinion's perception of renewable energy.

\section{References}

Alam, S. S., Hashim, N. H. N., Rashid, M., Omar, N. A., Ahsan, N., \& Ismail, M. D. (2014). Small-scale households renewable energy usage intention: Theoretical development and emprical settings. Renewable Energy, 68, 255-263.

Apak, G., \& Ubay, B. (2007). Türkiye İklim Değişikliği Birinci Ulusal Bildirimi (First National Communication of Turkey on climate change). Retrieved 2 March, 2015, from http://www.mgm.gov.tr/FILES/iklim/ulusalbildirimtr.pdf

Çelikler, D. (2013). Awareness about renewable energy of pre-service science teachers in Turkey. Renewable Energy, 60, 343-348.

Devine-Wright, P. (2007). Reconsidering public attitudes and public acceptance of renewable energy technologies: A critical review. Retrieved from http://geography.exeter.ac.uk/beyond_nimbyism/deliverables/bn_wp1_4.pdf

Ediger, V. Ş., \& Kentmen, Ç. (2010). Enerjinin Toplumsal Boyutu ve Türk Halkının Enerji Tercihleri (Social dimension of energy and energy choices of Turkish public). Mülkiye, 34(268), 281-300.

Eshchanov, B. R., Stultjes, M. G. P., Eschchanov, R. A., \& Salaev, S. K. (2011). People's perceptions on renewable energy sources' penetration prospects in the Khorezm Province, Uzbekistan. Retrieved from http://www.scientificpapers.org/wp-content/files/1237_Peoples_Perceptions_on_Renewable_Energy_SourcesPenetration_Pr ospectsintheKhorezm_Province_Uzbekistan.pdf

Howell, R., Shackley, S., \& Mabon, L. (2012). Public perceptions of low carbon energy technologies: Results from a Scottish Large Group Process. Retrieved from http://www.globalccsinstitute.com/sites/www.globalccsinstitute.com/files/publications/38531/scottishlgpreport.pdf

Karatepe, Y., Varbak Neşe, S., Keçebaş, A., \& Yumurtac1, M. (2012). The levels of awareness about the renewable energy sources of university students in Turkey. Renewable Energy, 44(1), 174-179.

Painuly, J. P. (2001). Barriers to renewable energy penetration: A framework for analysis. Renewable Energy, 24, 73-89.

Saraç, E., \& Bedir, H. (2014). Sınıf Öğretmenlerinin Yenilenebilir Enerji Kaynakları ile İlgili Algılamaları Üzerine Nitel Bir Çalışma (Primary school teachers related to perceptions of renewable energy sources on the qualitative research). KHO Bilim Dergisi, 24(1), 19-45.

Songsore, E., \& Buzzeli, M. (2014). "Social responses to wind energy development in Ontario: The influence of health risk perceptions and associated concern. EnergyPolicy, 69, 285-296.

Vaijayanthi, N. (2013). A study on public awareness and perception towards solar energy resource. Discovery Engineering, 1(1), 25-29. 
West, J., Bailey, I., \& Winter, M. (2010). Renewable energy policy and public perceptions of renewable energy: A cultural theory approach. Energy Policy, 38, 5739-5748.

Wüstenhagen, R., Wolsink, M., \& Bürer, M. J. (2007). Social acceptence of renewable energy innovation: An introduction to the concept. Energy Policy, 35, 2683-2691.

Yakut İpekoğlu, H., Üçgül, İ., \& Yakut, G. (2014). Yenilenebilir Enerji Algısı Anketi: Güvenirliği ve Geçerliği (Renewable energy perception scale: Reliability and validity). Journal of YEKARUM, 2(3), 20-26.

Zyadin, A., Puhakka, A., Ahponen, P., \& Pelkonen, P. (2014). Secondary school teachers' knowledge, perceptions, and attitudes toward renewable energy in Jordan. Renewable Energy, 62, 341-348. 